\title{
UPAYA MENINGKATKAN HASIL BELAJAR PKN DENGAN MENERAPKAN PEMBELAJARAN KONTEKSTUAL OLEH SISWA KELAS XI SMK PELITA HAMPARAN PERAK TAHUN PELAJARAN 2017/2018
}

\author{
Muhlis Fahdiar Sembiring \\ STKIP Budidaya Binjai
}

\begin{abstract}
Abstrak
Pembelajaran Pendidikan Kewarganegaraan (PKn) sering dianggap sebagai pembelajaran yang bersifat normatif sehingga dianggap tidak menarik dan membosankan. Padahal pelajaran PKn merupakan pelajaran penting dalam membelajarkan siswa untuk menjadi warga negara yang baik serta mengembangkan dan melestarikan nilai luhur dan moral sehingga nantinya dapat diwujudkan dalam bentuk perilaku kehidupan sehari-hari. Oleh karena itu perlu adanya perbaikan yang harus dilakukan guru dalam pola pengajarannya. Salah satunya adalah dengan menerapkan strategi belajar yang menarik. Salah satu pembelajaran yang dapat dilakukan adalah dengan menerapkan pembelajaran kontekstual. Adapun tujuan yang ingin dicapai dalam kegiatan penelitian ini adalah untuk mengetahui peningkatan hasil belajar PKn dengan menerapkan pembelajaran kontekstual oleh Siswa Kelas XI SMK Pelita Hamparan Perak tahun pelajaran 2017/2018.

Penelitian ini dilaksanakan di SMK Pelita Hamparan Perak Kab. Deli Serdang. Populasi dalam penelitian ini berjumlah 30 siswa, sedangkan subjek yang diambil dalam penelitian ini adalah 30 siswa.

Aktivitas guru dengan menerapkan pembelajaran kontekstual dalam mengajar pada siklus I menunjukan berkategori baik dan pada siklus II naik menjadi sangat baik.Aktivitas siswa dengan diterapkan pembelajaran kontekstual dalam mengajar pada siklus I menunjukan berkategori baik dan pada siklus II naik menjadi sangat baik.

Dari hasil perhitungan diperoleh nilai rata-rata pada siklus I sebesar 65 dengan ketuntasan klasikal 66,67\% sedangkan pada siklus II memperoleh nila rata-rata sebesar 81 dengan ketuntasan klasikal $100 \%$. Hal ini menunjukan terjadi perubahan yang baik dari hasil tes siklus I ke tes siklus II. Sehingga dapat disimpulkan bahwa terdapat peningkatan hasil belajar PKn dengan menerapkan pembelajaran kontekstual oleh Siswa Kelas XI SMK Pelita Hamparan Perak tahun pelajaran 2017/2018.
\end{abstract}

Kata Kunci : hasil belajar, pembelajaran kontekstual

\section{PENDAHULUAN}

Pendidikan kewarganegaraan dalam pengertian sebagai citizenship education, secara substantif dan pedagogis didesain untuk mengembangkan warga negara yang cerdas dan baik untuk seluruh jalur dan jenjang pendidikan. Pendidikan Kewarganegaraan (PKn) merupakan program pendidikan berdasarkan nilai-nilai pancasila sebagai wahana untuk mengembangkan dan melestarikan nilai luhur dan moral yang berakar pada budaya bangsa Indonesia yang diharapkan dapat menjadi jati diri yang diwujudkan dalam bentuk perilaku dalam kehidupan sehari-hari peserta didik baik sebagai individu, sebagai anggota masyarakat dan makhluk ciptaan tuhan Yang Maha Esa. 
Dalam pendidikan nasional pendidikan kewarganegaraan terbagi dalam lima status. Pertama, sebagai mata pelajaran disekolah. Kedua, sebagai mata kuliah di perguruan tinggi. Ketiga, sebagai salah satu cabang pendidikan disiplin ilmu pengetahuan sosial dalam kerangka program pendidikan guru. Keempat, sebagai program pendidikan politik yang dikemas dalam bentuk penataran pedoman penghayatan dan pengamalan pancasila (penataran P4). Kelima, sebagai kerangka konseptual dalam bentuk pemikiran individual dan kelompok pakar terkait, yang dikembangkan sebagai landasan dan kerangka berfikir mengenai pendidikan kewarganegaraan dalam empat status yang lain.

Terkait dengan status Pendidikan Kewarganegaraan (PKn) yang pertama yaitu sebagai mata pelajaran di sekolah, dalam perkembangannyapendidikan kewarganegaraan di Indonesia terutama untuk Madrasah Ibtidaiyah/Sekolah Dasar telah mengalami berbagai perubahan nama dengan sangat cepat karena mata pelajaran Pendidikan Kewarganegaraan (PKn) tersebut sangat rentan terhadap perubahan politik, namun isi secara umum dan pendekatan serta sistem penyampaiannya kebanyakan tidak berubah.

"Belajar adalah perubahan tingkah laku sebagai hasil dari pengalaman". "Belajar adalah proses perubahan tingkah laku pada diri individu berkat adanya interaksi antara individu dengan lingkungannya".Kemampuan orang untuk belajar ialah ciri penting yang membedakan jenis nya dari jenis makhluk hidup yang lain. Kemampuan yang memberikan manfaat bagi individu yang lain dan juga bagi masyarakat disekitarnya. Untuk memperoleh semua itu, kita harus memilki pendidkan. Pendidikan merupakan aspek yang tidak terlepas dari kehidupan manusia. Oleh karena itu pendidikan sangat menentukan dan penting bagi kemajuan sutu bangsa.

"Dalam kegiatan belajar mengajar banyak faktor yang mempengaruhi keberhasilan belajar, tetapi hal ini dapat digolongkan menjadi dua faktor, yaitu faktor intern dan faktor ekstern". Faktor intern dan faktor yang berasal dari dalam diri anak yang sedang belajar. Dan faktor ekstern adalah faktor yang berasal dari luar diri anak yang sedang belajar. Dalam penelitian ini, penulis akan meneliti faktor ekstern yaitu faktor yang berasal dari luar diri anak yang sangat menunjang keberhasilannya dalam belajar.

Pembelajaran Pendidikan Kewarganegaraan (PKn) sering dianggap sebagai pembelajaran yang bersifat normatif sehingga dianggap tidak menarik dan membosankan. Padahal pelajaran PKn merupakan pelajaran penting dalam membelajarkan siswa untuk menjadi warga negara yang baik serta mengembangkan dan melestarikan nilai luhur dan moral sehingga nantinya dapat diwujudkan dalam bentuk perilaku kehidupan sehari-hari. Pada umumnya, proses pembelajaran PKn masih banyak kita jumpai pembelajaran yang bersifat konvensional dimana terjadi pengalihan informasi dari guru ke siswa. Walaupun banyak siswa yang mampu menghapal materi yang diterimanya dengan baik, namun kenyataannya mereka seringkali tidak memahami secara mendalam substansi materinya. Sebagian besar siswa tidak mampu menghubungkan antara apa yang mereka pelajari dengan bagaimana pengetahuan tersebut akan dipergunakan. 
Oleh karena itu perlu adanya perbaikan yang harus dilakukan guru dalam pola pengajarannya. Salah satunya adalah dengan menerapkan strategi belajar yang menarik. Salah satu pembelajaran yang dapat dilakukan adalah dengan menerapkan pembelajaran kontekstual. "Pembelajaran kontekstual merupakan konsep belajar dimana guru menghadirkan dunia nyata ke dalam kelas dan mendorong siswa membuat hubungan antara pengetahuan yang dimilikinya dengan penerapannya dalam kehidupan mereka sebagai anggota keluarga dan masyarakat".

Berdasarkan latar belakang masalah di atas, maka penulis tertarik membahas hal tersebut dalam penelitian ini. Untuk ini dipilih Judul "Upaya Meningkatkan Hasil Belajar PKn Dengan Menerapkan Pembelajaran Kontekstual Oleh Siswa Kelas XI SMK Pelita Hamparan Perak Tahun Pelajaran 2017/2018".

\section{Pengertian Belajar}

Belajar adalah suatu aktivitas yang sangat penting dalam kehidupan manusia. Pengertian belajar sebagaimana dinyatakan Roestiyah adalah: "Menurut pendapat tradisional belajar itu hanya menambah dan mengumpulkan sejumlah ilmu pengetahuan." Dalam proses belajar, siswa harus aktif sehingga mampu membangun pemahaman dan kepercayaan dirinya serta dapat berinteraksi dengan lingkungannya.

Aktivitas belajar siswa mencakup dua aspek yang tidak terpisahkan, yakni aktivitas mental (emosional-intelektual-sosial) dan aktivitas motorik (gerak fisik). Kedua aspek ini berkaitan satu sama lain, saling mengisi dan menentukan. Jadi, keaktifan siswa yang optimal tidaklah hanya dilihat pada aktivitas motorik (gerak fisik) siswa, seperti melakukan diskusi, kerja kelompok, dan simulasi. Tetapi "keaktifan siswa yang optimal haruslah mencakup aktivitas mental dan aktivitas motorik".

\section{Hasil Belajar}

Istilah hasil belajar berasal dari bahasa Belanda "prestatie" atau dalam bahasa Indonesia menjadi prestasi yang berarti hasil usaha. Prestasi selalu dihubungkan dengan aktivitas tertentu, seperti yang dikemukakan oleh Abdullah bahwa dalam setiap proses akanselalu terdapat hasil nyata yang dpat diukur dan dinyatakan sebagai hail belajar (achievement) seseorang, sedangkan menurut Suryabrata bahwa hasil belajar termasuk dalam kelompok atribut kognitif, yang respons hasil pengukurannya tergolong pendapat (judgement), yaitu respon yang dapat dinyatakan benar atau salah. Seperti pernyataan Slameto bahwa "Belajar ialah suatu proses usaha yang dilakukan seseorang untuk memperoleh suatu perubahan tingkah laku yang baru secara keseluruhan sebagai hasil pengalamannya sendiri dalam interaksi lingkungannya".

Belajar mengakibatkan perubahan tingkah laku yang dicapai melalui suatu proses kegiatan dan usaha. Perubahan tingkah laku itu merupakan proses belajar, sedangkan perubahan tingkah laku itu sendiri merupakan hasil belajar, dan hasil belajar yang dicapai seorang individu merupakan hasil interaktif antara berbagai faktor yang memp Hasil belajar berarti sesuatu yang diadakan oleh suatu usaha belajar sesuatu yang diadakan itu adalah dalam bentuk tingkah laku 
yang baru atau dengan kata lain prestasi belajar (hasil belajar) merupakan tingkat penguasaan yang dicapai siswa setelah proses belajar dan pembelajaran dilaksanakan, sesuai dengan tujuan yang telah ditetapkan sebelumnya.

Hasil belajar merupakan ukuran kemampuan siswa memahami dan menguasai materi pelajaran dan pengetahuan serta kemampuan bertindak serta menggunakan pengetahuan tersebut untuk merubah perilaku menjadi lebih dewasa dan mampu memecahkan masalah. Pendidikan Kewarganegaraan adalah pendidikan demokrasi dan politik yang bertujuan untuk membentuk warga negara yang menyadari dan mampu melaksanakan hak dan kewajibannya untuk ikut berpartisipasi dalam pembangunan dan kemajuan negara.

Pembelajaran PKn adalah pembelajaran nilai dan moral pancasila dan UUD 1945 yang bermuara pada terbentuknya watak pancasila dan UUD 1945 dalam diri peserta didik. Dari uraian di atas maka hasil belajar PKn adalah ukuran kemampuan siswa memahami dan menguasai materi pelajaran dan pengetahuan serta kemampuan bertindak serta menggunakan pengetahuan tersebut untuk merubah perilaku sebagai hasilproses pendidikan demokrasi dan politik yang bertujuan untuk membentuk warga negara yang memiliki nilai, moral dan watak pancasila dan UUD 1945.

\section{Pendidikan Kewarganegaraan}

Menurut Dede, "Pendidikan kewarganegaraan adalah pendidikan yang cakupannya lebih luas dari pendidikan demokrasi dan pendidikan HAM". Sementara itu, Zamroni (dalam Dede Rosyada) berpendapat bahwa "Pendidikan Kewarganegaraan adalah pendidikan demokrasi yang bertujuan untuk mempersiapkan warga masyarakat berpikir kritis dan bertindak demokratis, melalui aktivitas menanamkan kesadaran kepada generasi baru bahwa demokrasi adalah bentuk kehidupan masyarakat yang paling menjamin hak-hak warga masyarakat".

Pendidikan kewarganegaraan merupakan mata pelajaran yang memfokuskan pada pembentukan warganegara yang memahami dan mampu melaksanakan hak-hak dan kewajibannya untuk menjadi warganegara Indonesia yang cerdas, terampil, dan berkarakter yang diamanatkan oeleh pancasila dan UUD 1945. Berdasarkan penjelasan dari pengertian tentang Pendidikan Kewarganegaraan (PKn) maka dapat disimpulkan bahwa pendidikan kewarganegaraan adalah pendidikan demokrasi dan politik yang bertujuan untuk membentuk warga negara yang menyadari dan mampu melaksanakan hak dan kewajibannya untuk ikut berpartisipasi dalam pembangunan dan kemajuan negara.

Karakteristik dapat diartikan sebagai ciri-ciri atau tanda yang menunjukan suatu hal berbeda dengan lainya. PKn sebagai mata pelajaran yang sangat penting bagi siswa memiliki karakteristik yang cukup berbeda dengan cabang ilmu pendidikan lainnya. Karakteristik PKn ini dapat dilihat dari objek, lingkup materinya, strategi pembelajaran, sampai pada sasaran akhir dari pendidikan ini. Pendidikan kewarganegaraan merupakan mata pelajaran yang memfokuskan pada pembentukan warga negara yang memahami dan mampu melaksanakan hak-hak dan kewajibannya untuk menjadi warganegara Indonesia yang cerdas, terampil, dan berkarakter yang diamanatkan 
oleh Pancasila dan UUD 1945.

\section{METODOLOGI PENELITIAN}

Penelitian ini dilaksanakan di SMK Pelita Kecamatan Hamparan Perak Kabupaten Deli Serdang. Penelitian dilakukan pada semester genap tahun pelajaran 2017/2018, lalu data itu dianalisis sesuai langkah-langkah dan konsep penelitian.

Dalam penelitian ini mengkaji hubungan dua variabel, yakni penggunaan lembar kerja siswa sebagai variabel bebas (x) dan hasil belajar sebagai variabel terikat (y) sehingga metode penelitian yang dipergunakan adalah metode deskripsif, yakni jenis penelitian deskriptif studi korelasi.

Berdasarkan kutipan tersebut dapat diartikan sebagai prosedur pemecahan masalah yang sedang diselidiki dengan menggambarkannya melukiskan keadaan subjek / objek penelitian pada saat sekarang berdasarkan fakta - fakta yang tampak atau bagaimana adanya. Berdasarkan judul penelitian maka jenis penelitian ini adalah penelitian tindakan kelas.

Penelitian ini adalah penelitian tindakan kelas (PTK) yang dilaksanakan dalam bentuk siklus berulang, yaitu jika pada siklus I setelah direfleksi kriteria keberhasilan tindakan belum tercapai, maka akan diperbaiki pada siklus berikutnya. Atau jika pada siklus I kriteria keberhasilan tindakan telah tercapai, maka kriteria keberhasilan tindakan pada siklus berikutnya akan ditingkatkan agar lebih baik lagi daripada siklus I.

Subjek dalam penelitian ini adalah semua siswa kelas XI SMK Pelita Hamparan Perak tahun pelajaran 2017/2018 yang jumlah seluruhnya sebanyak 30 orang. Instrumen yang digunakan dalam pengumpulan data dalam penelitian ini adalah :

1. Observasi

Observasi yang dilakukanmerupakan pengamatan terhadap seluruh kegiatan.Pada tahap ini guru PKn yang mengajar di kelas XI SMK Pelita Hamparan Perak mengobservasikan peneliti yang sedang melaksanakan pembelajaran dengan tujuan apakah belajar mengajar sudah terlaksana sesuai dengan skenario pembelajaran yang dilakukan sudah menjadi suatu kesatuan yang terorganisasi sudah saling berhubungan satu sama lain dalam rangka mencapai pembelajaran yang diinginkan.

2. Tes

Tes yang dipergunakan dalam penelitian ini bertujuan untuk melihat keberhasilan atau peningkatan hasil belajar siswa. Tes dalam penelitian ini adalah tes uraian sebanyak 10 soal.Dalam penyusunan tes penelitian mengambildaribukuPKn yang digunakan siswa yang sesuai dengan kurikulum tingkat satuan pendidikan, sehingga sebenarnya tidak perlu di uji cobakan karena sudah dianggap memenuhi validitasisi.

\section{Prosedur Penelitian}


Berdasarkan jenis penelitian ini, yaitu Penelitian Tindakan Kelas (PTK), peneliti memiliki beberapa tahap yang merupakan siklus. Tiap siklus dilaksanakan sesuai dengan perubahan yang akan dicapai. Pada penelitian ini akan dilaksanakan dalam 2 siklus, yaitu :

1. Tahap Perencanaan Penelitian

Kegiatan yang akan dilakukan dalam perencanaan tindakan adalah:

a. Membuat skenario pembelajaran.

b. Menyusun soal tiap siklus.

c. Membuat lembar observasi untuk melihat bagaimana kondisi belajar mengajar berlangsung.

2. Tahap Pelaksanaan Penelitian

Tahap pelaksanaan adalah pelaksanaan tindakan yang meliputi :

a. Melakukan kegiatan pembelajaran dengan menggunakan pembelajaran kontekstual.

b. Setelah pembelajaran pada akhir tindakan, siswa diberi soal latihan dan guru melihat hasil yang dicapai oleh siswa.

c. Memberikan kesempatan kepada siswa untuk menyelesaikan soal latihan yang dibuat di papan tulis.

d. Memberikan kesempatan kepada siswa untuk melakukan tanya jawab mengenai soal latihan yang diberikan.

e. Memberikan tes untuk mengetahui bagian mana dari materi yang kurang dipahami siswa.

f. Melakukan wawancara kepada siswa yang kurang paham akan materi.

3.Tahap Observasi

Observasi dilakukan di dalam kelas ketika kegiatan belajar mengajar berlangsung. Observasi dilakukan oleh guru PKn kelas XI SMK Pelita Hamparan Perak. Hasil observasi akan diserahkan kembali kepada peneliti untuk mengetahui sejauh mana keterampilan belajar siswa.

4. Tahap Refleksi

Hasil yang didapatkan pada tahap pelaksanaan tindakan dan wawancara serta observasi dikumpulkan dan dianalisa pada tahap refleksi sehingga diperoleh kesimpulan dari tindakan yang dilakukan. Hasil refleksi digunakan sebagai dasar untuk tahap perencanaan pada siklus berikutnya. Secara lebih rinci, prosedur pelaksana tindakan kelas.

Selanjutnya, analisis data dalam penelitian ini dilakukan dalam beberapa tahap, yaitu :

1. Reduksi Data

Proses mereduksi data dilakukan dengan menyeleksi, menyederhanakan, dan mentransformasikan data yang telah disajikan dalam bentuk transkrip catatan lapangan. Kegiatan mereduksi data ini bertujuan untuk mengetahui tingkat pemahaman materi.

2. Memaparkan Data

Setelah direduksi, data siap dipaparkan. Artinya, tahap analisa sampai pemaparan data. Dari analisa data diperoleh hasil belajar siswa di mana hasil belajar siswa, baik per orangan 
maupun klasikal berdasarkan nilai Kriteria Kumulatif Minimal sesuai dengan kurikulum tingkat satuan pembelajaran.

1. Seorang siswa dikatakan telah tuntas belajar apabila siswa tersebut telah mencapai skor $65 \%$ atau nilai 65.

2. Suatu kelas dikatakan telah tuntas belajar apabila terdapat $85 \%$ yang telah mencapai daya serap lebih dari atau sama dengan $65 \%$.

Untuk melihat peningkatan yang terjadi dalam pembelajaran yang sedang berlangsung, dilakukan analisa data dari tes awal dengan melakukan langkah-langkah sebagai berikut :

a. Ketuntasan belajar perseorangan dapat dihitung dengan menggunakan rumus :

$\mathrm{D}=\frac{X}{X i} \times 100 \%$

Keterangan :

$\mathrm{D}=$ Ketuntasan Individu yang telah dicapai dengan daya serap $>65 \%$

$\mathrm{X}=$ Jumlah siswa yang telah dicapai dengan daya serap $<65 \%$

$\mathrm{Xi}=$ Jumlah siswa

Dengan kriteria :

$0 \% \leq \mathrm{D}<65 \%=$ Siswa belum tuntas dalam belajar

$65 \% \leq \mathrm{D} \leq 100 \%=$ Siswa telah tuntas dalam belajar

b. Ketuntasan belajar klasikal dapat dihitung dengan menggunakan rumus:

$\mathrm{D}=\frac{X}{N} \times 100 \%$

Keterangan :

$\mathrm{D}=$ persentase ketuntasan klasikal

$\mathrm{X}=$ skor yang diperoleh siswa

$\mathrm{N}=$ skor maksimum

Berdasarkan hasil musyawarah guru mata pelajaran (MGMP) Pkn, maka nilai Kriteria

Ketuntasan Minimal adalah 65. Apabila siswa mencapai nilai tersebut atau lebih besar, maka dikategorikan tuntas, tetapi bila kurang dari nilai tersebut maka siswa dikategorikan belum tuntas.

3. Menganalisis Hasil Belajar Siswa Dengan Observasi

Dari hasil lebar observasi yang dilakukan oleh observe, di analalisis menggunakan analisis persentase. Untuk analisis persentase digunakan rumus

$\mathrm{P}=\frac{S}{N} \times 100 \%$

Keterangan :

P : Persentase Pelaksanaan tiap indikator

S : Jumlah Skor yang diperoleh untuk setiap indikator 
N : Jumlah Skor Total

Ketentuan :

$75 \% \leq P \geq 100 \% \quad:$ Aktif

$0 \% \leq P<75 \% \quad$ : Kurang Aktif

Dengan demikian, aktivitas belajar siswa dapat meningkat apabila telah mencapai persentase sebesar $75 \%$.

\section{HASIL PENELITIAN DAN PEMBAHASAN}

\section{Siklus I}

Pada siklus ini dilakukan langkah-langkah pembelajaran sebagai berikut:

\section{a. Tahap Perencanaan}

Dengan ditemukannya kesulitan yang diawali dalam siswa dalam memahami materi maka peneliti membuat alternatif pemecahan terhadap hasil belajar dengan menggunakan pembelajaran kontekstual, dimana peneliti bertindak sebagai guru. Pada tahap ini direncanakan pada siklus I, yaitu :

1. Menyusun skenario pembelajaran.

2. Membuat lembar aktivitas siswa.

3. Menyusun soal tes yang digunakan untuk melihat hasil belajar siswa.

4. Membuat lembar observasi guru untuk melihat kondisi belajar mengajar berlangsung dan melihat upaya yang dilakukan guru.

\section{b. Tahap Pelaksanaan Tindakan I}

Pada siklus ini, pemberiaan tindakan dilakukan dengan kegiatan belajar mengajar dimana peneliti bertindak sebagai guru. Kegiatan belajar yang dilakukan merupakan pengembangan dan pelaksanaan dari rencana pelaksanaan pembelajaran yang disusun pada saat perencanaan. Rencana Pelaksanaan Pembelajaran (RPP) pada siklus I. Metode pembelajaran yang digunakan adalah pembelajaran kontekstual secara klasikal yang difokuskan pada proses belajar yang dapat meningkatkan hasil belajar siswa. Dalam pelaksanaan tindakan sebagai upaya meningkatkan hasil belajar siswa, langkah-langkah yang dilakukan adalah :

1. Melakukan kegiatan pembelajaran dengan pembelajaran kontekstual, dengan langkahlangkah sebagai berikut:

a. Guru menjelaskan konmpetensi yang harus dicapai serta manfaat dari proses pembelajaran dan pentingnya materi pelajaran yang akan dipelajari.

b. Guru menjelaskan prosedur pembelajaran kontekstual dengan cara membagi siswa dalam beberapa kelompok sesuai jumlah siswa, tiap kelompok ditugaskan untuk melakukan observasi, melalui observasi siswa ditugaskan untuk mencatat berbagai hal yang ditemukan. 
c. Guru melakukan tanya jawab sekitar tugas yang harus dikerjakan oleh siswa.

d. Siswa melakukan observasi dan mencatat hal-hal yang mereka temukan pada proses observasi.

e. Siswa mendiskusikan hasil temuan mereka sesuai dengan kelompoknya masingmasing.

f. Siswa melaporkan hasil diskusi.

g. Setiap kelompok menjawab pertanyaan yang diajukan oleh kelompok lain.

h. Dengan bantuan guru siswa menyimpulkan hasil observasi.

i. Guru melakukan refleksi

2. Peneliti bertindak sebagai guru dan melibatkan satu orang sebagai pengamat yang memberikan masukan tentang pembelajaran yang sedang berlangsung.

3. Pada akhir pertemuan siswa diberi tes hasil belajar yang dikerjakan secara individu sebagai evaluasi pelaksanaan pembelajaran.

4. Dari hasil analisis hasil tes belajar tersebut akan diketahui siswa yang belum tuntas belajar.

5. Data yang diperoleh dari siklus I, data dianalisis melalui tahap-tahap yaitu mendiskusikan data dan menyajikan data.

\section{c. Tahap Observasi}

Observasi dilakukan bersamaan dengan tahap pelaksanaan tindakan I, yaitu ketika kegiatan belajar-mengajar berlangsung. Observasi dilakukan oleh guru pkn.

1. Observasi Aktivitas Guru Siklus I

Dari observasi yang dilakukan oleh observer dengan menggunakan lembar observasi aktivitas guru pada pelaksanaan Siklus I, pada pertemuan siklus I aktivitas guru sebesar 71,5\% dengan kategori baik sedangkan pada pertemuan II siklus I sebesar 100\% dengan kategori sangat baik dan pada pertemuan III siklus I sebesar 100\% dengan kategori baik. Berdasarkan observasi guru yang diperoleh pada pertemuan I, sikap guru selamam pembelajaran dengan menggunakan pembelajaran kontekstualsudah berjalan baik.

2. Lembar Observasi Siswa

Berdasarkan observasi yang dilakukan oleh observer yaitu guru bidang studi PKn pada pelaksanaan siklus I aktivitas siswa pada pertemuan I sebesar 85,5\% dengan kategori cukup sedangkan pada pertemuan II sebesar 71,4\% dengan kategori sangat baik serta pada pertemuan III sebesar 85,5\% dengan kategori snagat baik. Sehingga dapat disimpulkan bahwa aktivitas siswa berjalan dengan baik dalam pelaksanaan pembelajaran dengan pembelajaran kontekstual berjalan dengan cukup baik.

Dikarenakan masih adanya kekurangan guru dalam melaksanakan tindakan maka perlu adanya masukan yang harus diperbaikan pada pertemuan berikutnya. 
Adapun saran observer kepada penelitian untuk perbaikan pada pembelajaran selanjutnya sebagai berikut :

a. perhatikan siswa dalam berdiskusi.

b. Lebih memotivasi siswa untuk bertanya.

c. Penyampaian bahan ajar lebih menarik.

d. Efisiensi waktu disesuaikan dengan skenario pembelajaran yang telah dibuat.

\section{d. Refleksi}

Data yang diperoleh dari tes hasil belajar siklus I, observasi dan wawancara dianalisis melalui 4 tahap yaitu reduksi data, paparan data, verifikasi dan menarik kesimpulan.

\section{Reduksi Data}

Reduksi bertujuan untuk mentransformasikan data yang diperoleh dari lapangan ke dalam bentuk transkrip catatan. Data nilai siswa yang diperoleh dari tes siklus I terdapat pada lampiran.

\section{Paparan Data}

Setelah dilakukannya pembelajaran yang terdiri dari 2 kali pertemuan pada siklus I yang kemudian dilakukan tes kemampuan pada siklus I didapat hasil tes siswa.

KETUNTASAN BELAJAR SISWA SIKLUS I

\begin{tabular}{|c|c|c|c|c|}
\hline NO & $\begin{array}{c}\text { PRESENTASE } \\
\text { KETUNTASAN }\end{array}$ & $\begin{array}{c}\text { TINGKAT } \\
\text { KETUNTASAN }\end{array}$ & $\begin{array}{c}\text { BANYAK } \\
\text { SISWA }\end{array}$ & $\begin{array}{c}\text { PERSENTASE } \\
\text { JUMLAH } \\
\text { SISWA }\end{array}$ \\
\hline 1 & $<65 \%$ & Tidak tuntas & 10 & $33,33 \%$ \\
\hline 2 & $\geq 65 \%$ & Tuntas & 20 & $66,67 \%$ \\
\hline \multicolumn{2}{|r|}{ Jumlah } & 30 & $100 \%$ \\
\hline
\end{tabular}

Berdasarkan tabel di atas diketahui bahwa siswa yang mencapai ketuntasan individu sebanyak 20 orang siswa sedangkan 10 orang siswa belum mencapai ketuntasan individu. Rata-rata nilai yang diperoleh siswa pada tes kemampuan awal sebesar 65. Berdasarkan tabel 4.2 di atas dapat disimpulkan bahwa ketuntasan klasikal sebesar $66,67 \%$ atau belum mencapai ketuntasan klasikal atau di bawah $85 \%$, maka penelitian dilanjutkan pada siklus berikutnya (siklus II).

\section{Siklus II}

\section{a. Tahap Perencanaan}

Dengan ditemukannya kesulitan yang diawali dalam siswa dalam memahami materi maka peneliti membuat alternatif pemecahan terhadap hasil belajar dengan menggunakan pembelajaran kontekstual, dimana peneliti bertindak sebagai guru. Pada tahap ini direncanakan pada siklus I, yaitu :

1. Menyusun skenario pembelajaran. 
2. Membuat lembar aktivitas siswa.

3. Menyusun soal tes yang digunakan untuk melihat hasil belajar siswa.

4. Membuat lembar observasi guru untuk melihat kondisi belajar mengajar berlangsung dan melihat upaya yang dilakukan guru.

\section{b. Tahap Pelaksanaan Tindakan I}

Pada siklus ini, pemberiaan tindakan dilakukan dengan kegiatan belajar mengajar dimana peneliti bertindak sebagai guru. Kegiatan belajar yang dilakukan merupakan pengembangan dan pelaksanaan dari rencana pelaksanaan pembelajaran yang disusun pada saat perencanaan. Rencana Pelaksanaan Pembelajaran (RPP) pada siklus I. Metode pembelajaran yang digunakan adalah pembelajaran kontekstual secara klasikal yang difokuskan pada proses belajar yang dapat meningkatkan hasil belajar siswa. Dalam pelaksanaan tindakan sebagai upaya meningkatkan hasil belajar siswa, langkah-langkah yang dilakukan adalah:

1. Melakukan kegiatan pembelajaran dengan pembelajaran kontekstual, dengan langkah-langkah sebagai berikut:

a. Guru menjelaskan konmpetensi yang harus dicapai serta manfaat dari proses pembelajaran dan pentingnya materi pelajaran yang akan dipelajari.

b. Guru menjelaskan prosedur pembelajaran kontekstual dengan cara membagi siswa dalam beberapa kelompok sesuai jumlah siswa, tiap kelompok ditugaskan untuk melakukan observasi, melalui observasi siswa ditugaskan untuk mencatat berbagai hal yang ditemukan.

c. Guru melakukan tanya jawab sekitar tugas yang harus dikerjakan oleh siswa.

d. Siswa melakukan observasi dan mencatat hal-hal yang mereka temukan pada proses observasi.

e. Siswa mendiskusikan hasil temuan mereka sesuai dengan kelompoknya masingmasing.

f. Siswa melaporkan hasil diskusi.

g. Setiap kelompok menjawab pertanyaan yang diajukan oleh kelompok lain.

h. Dengan bantuan guru siswa menyimpulkan hasil observasi.

i. Guru melakukan refleksi

2. Peneliti bertindak sebagai guru dan melibatkan satu orang sebagai pengamat yang memberikan masukan tentang pembelajaran yang sedang berlangsung.

3. Pada akhir pertemuan siswa diberi tes hasil belajar yang dikerjakan secara individu sebagai evaluasi pelaksanaan pembelajaran.

4. Dari hasil analisis hasil tes belajar tersebut akan diketahui siswa yang belum tuntas belajar. 
5. Data yang diperoleh dari siklus I, data dianalisis melalui tahap-tahap yaitu mendiskusikan data dan menyajikan data.

\section{c. Tahap Observasi}

Observasi dilakukan bersamaan dengan tahap pelaksanaan tindakan II, yaitu ketika kegiatan belajar-mengajar berlangsung. Observasi dilakukan oleh guru matematika.

\section{Lembar Observasi Aktivitas Guru Siklus II}

Dari observasi yang dilakukan oleh observer dengan menggunakan lembar observasi aktivitas guru pada pelaksanaan Siklus II, pada pertemuan I aktivitas guru sebesar 60\% dengan kategori baik sedangkan pada pertemuan II sebesar $80 \%$ dengan kategori sangat baik dan pada pertemuan III sebesar 100\% dengan kategori sangat baik.

Berdasarkan observasi guru yang diperoleh pada pertemuan II, sikap guru selamam pembelajaran dengan menggunakan pembelajaran kontekstualsudah berjalan baik.

\section{Lembar Observasi Siswa}

Berdasarkan observasi yang dilakukan oleh observer yaitu guru bidang studi PKn pada pelaksanaan siklus II aktivitas siswa sebesar 100\% dengan kategori baik sedangkan pada pertemuan II sebesar 60\% dengan kategori sangat baik dan pada pertemuan III sebesar $80 \%$ dengan kategori sangat baik. Sehingga dapat disimpulkan bahwa aktivitas siswa berjalan dengan baik dalam pelaksanaan pembelajaran dengan pembelajaran kontekstual berjalan dengan baik.

\section{d. Refleksi}

Data yang diperoleh dari tes hasil belajar siklus II, observasi dan wawancara dianalisis melalui 4 tahap yaitu reduksi data, paparan data, verifikasi dan menarik kesimpulan.

\section{Reduksi Data}

Reduksi bertujuan untuk mentransformasikan data yang diperoleh dari lapangan ke dalam bentuk transkrip catatan. Data nilai siswa yang diperoleh dari tes siklus II.

\section{Paparan Data}

Setelah dilakukannya pembelajaran yang terdiri dari 3 kali pertemuan pada siklus II yang kemudian dilakukan tes kemampuan pada siklus II didapat hasil tes siswa.

KETUNTASAN BELAJAR SISWA SIKLUS II

\begin{tabular}{|l|l|l|l|l|}
\hline NO & $\begin{array}{l}\text { PRESENTASE } \\
\text { KETUNTASAN }\end{array}$ & $\begin{array}{l}\text { TINGKAT } \\
\text { KETUNTASAN }\end{array}$ & $\begin{array}{l}\text { BANYAK } \\
\text { SISWA }\end{array}$ & $\begin{array}{l}\text { PERSENTASE } \\
\text { JUMLAH } \\
\text { SISWA }\end{array}$ \\
\hline 1 & $<65 \%$ & TIDAK & 0 & $0 \%$ \\
\hline
\end{tabular}




\begin{tabular}{|l|l|l|l|l|}
\hline & & TUNTAS & & \\
\hline 2 & $\geqslant 65 \%$ & TUNTAS & 30 & $100 \%$ \\
\hline \multicolumn{2}{|l|}{ JUMLAH } & 30 & $100 \%$ \\
\hline
\end{tabular}

Berdasarkan tabel di atas diketahui bahwa siswa yang mencapai ketuntasan individu sebanyak 30 orang siswa mencapai ketuntasan individu. Rata-rata nilai yang diperoleh siswa pada tes kemampuan siklus II sebesar 81. Berdasarkan tabel 4.4 di atas dapat disimpulkan bahwa ketuntasan klasikal sebesar 100\% atau telah mencapai ketuntasan klasikal, maka penelitian ini tidak perlu dilanjutkan pada siklus berikutnya (siklus III).

\section{KESIMPULAN}

Berdasarkan hasil penelitian yang terdapat pada Bab IV dapat disimpulkan bahwa:

1. Aktivitas guru dengan menerapkan pembelajaran kontekstual dalam mengajar pada siklus I menunjukan berkategori baik dan pada siklus II naik menjadi sangat baik.

2. Aktivitas siswa dengan diterapkan pembelajaran kontekstual dalam mengajar pada siklus I menunjukan berkategori baik dan pada siklus II naik menjadi sangat baik.

3. Dari hasil perhitungan diperoleh nilai rata-rata pada siklus I sebesar 65 dengan ketuntasan klasikal 66,67\% sedangkan pada siklus II memperoleh nila rata-rata sebesar 81 dengan ketuntasan klasikal 100\%. Hal ini menunjukan terjadi perubahan yang baik dari hasil tes siklus I ke tes siklus II. Sehingga dapat disimpulkan bahwa terdapat peningkatan hasil belajar PKn dengan menerapkan pembelajaran kontekstual oleh Siswa Kelas XI SMK Pelita Hamparan Perak tahun pelajaran 2017/2018.

\section{REFERENSI}

Ali, Muhammad. Penelitian Pendidikan Prosedur dan Strategi. Bandung : Angkasa, 2009.

Arikunto, Suharsimi. Prosedur Penelitian. Jakarta: Rineka Cipta. 2011.

Dede Rosyada, dkk, Buku Panduan Dosen Pendidikan Kewargaan (Civic Education) Demokrasi, Hak Asasi Manusia, dan Masyarakat Madani, Jakarta: Prenada Media, 2004.

Fajar, Arnie. Portofolio dalam Pembelajaran IPS. Bandung : Remaja Rosdakarya, 2002. Jauhar, M. Implementasi PAIKEM. Jakarta ; Prestasi Pustakarya.2011.

Nurhadi. Pembelajaran Kontekstual dan Penerapannya dalam KBK. Malang : Universitas Negeri Malang. 2004.

Nasution, S. Buku Penuntun Membuat Desertasi, Thesis, Raport dan Peper. Bandung : Jemmars. 1992.

Poerwadarminta, WJS. Kamus Umum Bahasa Indonesia Jakarta: Balai Pustaka, 2002.

Roestiyah, NK. Masalah-Masalah Ilmu Keguaruan. Jakarta : bina Aksara. 1988.

Rosalin, Ellin, Gagasan Merancang Pembelajaran Kontekstual, Bandung: Karsa Mandiri Persada, 2008. 
Sanjaya, Wina. Strategi Pembelajaran Berorientasi Standar Proses Pendidikan. Jakarta: Kencana. 2006.

Slameto. Belajar dan Faktor-Faktor Yang Mempengaruhinya. Jakarta : Rineka Cipta. 2010.

Sudjana, Nana.Dasar-dasar Proses Belajar Mengajar. Bandung: Sinar Baru Algesindo, 2002.

Suprijono, Agus, Cooperative Learning Teori dan Aplikasi Paikem, Yogyakarta: Pustaka Pelajar, 2013.

Sugiono. Statistik Untuk Penelitian Bandung: Alphabeta, 2011.

Surakhman, Winarno. PengantarPenelitian Ilmiah Dasar. Bandung : Tarsito, 2002.

Sudjana, Metode statistika, Bandung, Tarsito. 2005.

Usman, M. Uzer. Menjadi Guru Profesional. Bandung : Remaja Rosdakarya. 2010. 